\title{
The System of Symbols in The Ritual of Rice Planting in Tonsea Ethnic
}

\author{
$1^{\text {st }}$ Grace Shirley Luntungan \\ French Education Department \\ Universitas Negeri Manado \\ Manado, Indonesia \\ graceluntungan@unima.ac.id
}

\author{
$2^{\text {nd }}$ Nicolas Gosal \\ French Education Department \\ Universitas Negeri Manado \\ Manado, Indonesia \\ nicolasgosal@unima.ac.id
}

\author{
$3^{\text {rd }}$ Prilimercy Engelien Kojongian \\ French Education Department \\ Universitas Negeri Manado \\ Manado, Indonesia \\ prilimercykojongian@unima.ac.id
}

\begin{abstract}
This research was focused on the study of the forms, meanings, and the functions of the symbols. This research was aimed at describing and explaining the system of symbols that were found on ritual of rice planting in Tonsea ethnic. This research can be classified as a case study using eclectic approach which combines theories of semiotics and hermeneutics. The finding of the forms of symbols include verbal symbol and nonverbal symbol. The findings of the meanings of symbols are in the context of: religion, ethics, aesthetics, and philosophy. The findings of the functions of symbols include symbols as: knowledge, communication, participation, and mediation.
\end{abstract} Ethnic

Keywords - symbols system, ritual of rice planting, Tonsea

\section{INTRODUCTION}

Rice has been known as the main leading food crop besides corn, and it is considered as divine food due to the fact that it was stolen from the wraith world of Tumileng. Formerly, rice was planted in the field. Rice cultivation was introduced in 1850's, which later decreased. Currently, most fields are changed to a farm, which is used for cultivating trade plants [1]. However, the rural community of Wangurer as the livelihood is preserving rice cultivation. They only rely on rainwater to hose the rice plants since their rural area is located on the hills, which is difficult to find water from the river. Therefore, they plant the rice in rainy season (in October, November, and December).

Rice cultivation for the local community, dominantly Tonse ethnic, is a sacred activilty, so they hold a kind of ritual led by tonaas to supplicate Opo Empung (a divine title as the supreme lord) in order to obtain abundant of corps, no danger or misfortune such as a rat and snake which damage the rice plants before the harvest. Tonaas derived from the word tou and taas; tou=orang (people), taas $=$ kebal and kuat (invulnerable and strong). His duty is to control the lands and farms. He also interprets the signs from bird sound and adepts at tricking away rats, wild pigs, monkeys, snakes, and the other harmful field pests [2]. The ability of Tonaas is considered as inheritance from his ancestors known as opo-opo considered living until they got authority, majority, and honor, while several opo' is considered as the intermediatary between The Supreme Lord and human. The word opo is closely related to the family fellowship, descent, kinship, and the wider community, and it therefore means based on the function/role/responsibility of the father as: the guardian, the guard, the protector, the helper, the defender, and so forth which is parallel with it [2].

As an essential and fundamental tradition, the ritual of rice cultivation expresses or presents the construction of the Tonsea cultural values, which in their presence and position present a symbol system containing cultural values in the process of cultural dialectics. According to Geertz [3], a symbol could synthesize a nation's ethos regarding its tone, character, quality of life, style, taste, morals, and aesthetics, as well as its outlook. Therfeore, in the ritual of Tonsea ethnic in Wangurer, it finds particular symbols. These symbols have a system, which relate and complete to each other to join the ritual entity of rice planting.

A symbol system is a set of symbolic elements, which relates and connects to each other in order to form a totality. Infact, the symbolic systems that individuals applied in negotiating meaning are systems that were ones already in use, already internalized deeply in a existing culture and language. Geertz [3] states that symbol in a social context are represented in its system. Interpreting symbolic system by finding its authentic meaning is one of the ways to construe a culture. Geertz synthesized that culture is a pattern of meaning that is historically spred, embodied in symbols. A system of concept inherited and diclosed in the forms of the symbols that become a means of expressing, recording and developing knowledge on the attitudes toward life. The forms of symbols in certain social context embody a pattern or system that is called culture. Interpreting a culture means interpreting system of symbol forms in order to derive its authentic meaning. Thus, the core of cultural studies is a meaning that is embodied in symbol; concept that is revealed in the forms of symbols. 
The ymbolic system in the rice cultivating ritual can be realized into segments, including the form of symbols, symbol meanings, and symbol functions. Symbols in the rice planting ritual are displayed in verbal and non-verbal forms. Herusatoto in Dharmojo [4] explains that the form of symbol can be in the form of language (story, parable, peom, poetry, and proverb), the body movement (dances), sound or voice (song, music), color and look (painting, decoration, sculpture, building). According to Eco [5], a system of symbol can refer to the language, which is related to the artworks, tradition, and religion in a certain community. The high value of the symbol makes the human language as a usefule tool for the speakers. Human language is a symbol of feelings, willingness, hopes, etc. In short, human is a symbol for human life, the symbol of the human itself. Language is a symbol, which can refer to the all aspects of multi objects, events, the relationship between object and events. What stated by Devito is explained by the following statement "which catalog the numerous objects and relation in the world" ([6].

Spradley [7] argues that symbol is an object or event of anything which refers to a certain issue. All symbols involve three elements: symbol itself, one or more reference, and the relationship between symbol and what is being referred. These three elements are being fundamental for all the symbolic purpose. This symbol includes what is being felt and experienced.

Human is a cultural creature, which cannot be separated from the symbols of interaction in community. Symbolism has colored human activities such as attitudes, sciences, and religions. It has an essential role for religion. Koentjaraningrat, ([8] states that components which should pay attention on in studying the concept of religion such as: 1) expression of trust as a behaviour in the form of actors and speech that was born as an emotional reflection shown to an object influenced to its life; 2) ritual system as the conventional procedures rules, or principles which have been applied and agreed by certain communities.

\section{RESEARCH METHODS}

This is qualitative research based on the eclectic approach as the combination of Semiotics Theory referred to Eco's view [5] and Hermeneutics Theory according to Ricouer Participative observation and interview become the method of data collection, and the data analysis applied from Miles and Huberman in Interactive-Dialective Method [9].

\section{RESULT AND DISCUSSION}

Ritual is presented as the verbal and non-verbal symbol in paralinguistic such as stated sentences, physics or objects, objects in the form of entity or material as the supporting ritual implementation, actions by ritual practitioners, and setting or background of a place, a time, and a situation or ambience in the ritual performance.

\section{A. The Form of Symbol Verbal}

Paralinguistics with sound characteristics such as mis, berbisik (whispering), suara meninggi (high voice), etc which are in and accompany someone's voice in language [10]. In the ritual of rice cultivation, si Tonaas begins to pray with hiss voice and say pleading voice in hard and high voice while serving offering. It is conducted to create ritual situation, and it has magical power in order to presence opa in that place. This is the following prayer:

\section{Before Rice Planting}

Iya wo tatadingan ni Opo Empung, Opo Tumideng, opo Mamengkas, Dotu Karema, Dotu Timani, Dotu Pasela um banua. Iyana tatadingan ni Opo Empung limeos untana wo u dangit umbeya umpiri-piri wia um bawo un tana akaran un tou wia rege-regesan. Wia ung kaweiten Opo Empung niaku kumeret pelako iyana u dudi, dudipe lako wia umbene yaay wo wia ne makeror. Kare †an man kine opo iyana umbene yaay, iyana woya tumou man kine mane rumari-raris umbene yaay, wean ta molako kine dudi pasomboran, dudi werot, dudi rahi, serewung rirem , samaran, tontoansen, dudi pakatuan. Kuramokan kine ung kasombor ung dudi yaay teintu mokan kine kasombor wia um bene wo wia ni tou si makeror yaay. Iyana wo tatadingan opo Empung pakatuan mokan kine um bene yaay akar kine umbene yaay upuen lako se makauma yaay. Kita mawadi-wadi pelako dumudi Pelako wia um bene ikeror wo nu makeroren yaay.

'Please listen Opa Empung, Opa Tumideng, Opa Mamengkas, Dotu Karema, Dotu Timani, Dotu Pasela Umbanua. Oh, God who preserves the sky and the earth, right now I am begging for bless of the rice corps and of the people who cultivate. I offer the plants of dudi, dudi pasombor, dudi werot, dudi rahi, black sereung, samara, tontoansen, and dudi pakatuan. As well as the fertility of this dudi, please also give fertility to the rice and give bless to the harvest. Oh God, listen, please extend the age this corps, and they can be harvested by the owner of the farm. We, all together and accept this dudi for the sake of rice and people who are cultivating'.

\section{1) After Rice Planting}

Tatadingan ni opo Empng iyana limeos un tana wo $\mathrm{u}$ dangit. Endo kaweiten opo, mapatau lako niko iyana ikeroro lako sana umaan yaay. Teintu mokan katcrang niendonu wowoondoan yaay teintumo katerang ung numa yaay kimeror lako endo nania. Kaweiten ne opo sanawiawia kampe kamu iyana tinawa iyana ninawuan iyana um bene yaay kimeror. Karengan man kine ya pakedu-kedungan niu mokan watu yaay numa yaay wo simbe-simbelannu lako simbel atep simbel iyana wo piki-piki mu lako dukun tana tembir tana se sakit wo ei siminasa iya wia ni opo na numa yaay. Endo kaweiten yaay raimo lako iyana opo wia na numa yaay tumuur lako nania wo mange. Endo kaweiten opo iyana dudi antamolako iyana sumaup iyana um bene, um bene tumoumane kine rumari-raris iyana kuramokan kasombor iyana dudi yaay teintu mokan kasombore iyana um bene yaay tumou iyana wo neikcror. Endo kaweiten tumuur lako nania wo mange opo piki mo lako ikuntana tembir un tana se sakit ei siminasa wo se koko lewo un tarndem ne tou moupi wo kapa pasuwang iyana mana Niu iyana na numa yaay kapa tou naan genang lewo Opo karcngan man sia kapunanu lako iyana akad kine sia pawadi-wadin niu mokan. Sanawia-wia kampe kamu opo iyana tinawa wiak na wua um bene yaay iyana poken iyana ung santi yaay iyana dukaren molako iyana tou lewo. Tou lewo genang iyana karengan man sia opo mapalelewo iyana um bene yaay tumou iyana kapaar mo male pasaniwensaniwen tou iyana kasuat tou iyana opo karengan man kine 
sia pongkolen niu molako iyana u dee na iyana karengan man kine wo kine sia pawadi-wadin niu mokan sia sa sia tuama iyana opo mawawan ung sompoy niu. Sasia wewene opo mange madutu nikamu. Ai tinakuraan opo iyana setou madangko-dangkoy iya magenang-genang lewo iyana wia numa yaay kapa mana niu wia numa yaay kapa ma dedo Numa yaay iyana kenu kata opo iyana ung santi iyana pongkolen niu molako nsia iyana wo sia palowa-lowaan niu moat wo endoan niu mo ange ate sia wo ung pusuna iyana karengan ange iyana sepsepen niu daa na akar wo sia pawadi-wadin niu mokan. Tumuur mo lako endo nania wo mange. Endo kaweiten opo iya tutudan nolako iyana makeror.

'Please hear us, dear God who has created the earth and the sky, now I have planted the paddies in this field. As the bright rays of the sun this morning, we hope that the planted paddies grows well. Dear God, as all Opo who will protect these rice are here, please protect these paddies from harms and pests. Please keep this rice field safe from harm now and forever. Protect these rice field so that it will be under your safe haven dear God. May everyone who will harm these paddies and do evil deeds be beheaded; their blood will be drained and their heart and liver be taken away. If the person is a man, make him be your loyal servant who carries your sarong; if the person is a woman, make her cook for you. Dear God, thrive these paddies and make them grow well as the dudi plant from now and forever. Now, we will keep all everything we use to plant these paddies.

The prayer ends as the farmers throw the dudi plant while enumerate the odd numbers, esa, tedu, dima, pitu, siow...(one, three, five, seven, nine).

\section{2) Non Verbal}

The non verbal symbols presented in this paper include physical materials or objects, as well as actors and participants of the ritual who take part in the ritual. The participants of the ritual are tonaas, the owners of the rice field, and everyone invited to help to process of rice planting. The preparation for the ritual begins with making offerings (sumowo tetengaan) by tonaas. This initial preparation has the important meaning for the local people because they have to prepare for offerings for Opo-opo, the highest supernatural ruler. The offering also serves as their tribute to these opos so they are willing to get rid of harm and give the protection and strength for the plants and the farmers. The people believe that the offerings will make these opos to grants their wishes. The offerings consist of following ingredients::

1. 9 Areca or Betel Nuts (wua) which have been splitted

2. Lime Betel $(a p u)$

3. Folded tobacco (nides)

4. Tobacco (tawaku kalampamg) (the splitted betel nut and the lime betel wrapped by using tobacco leaves and this wrap will be eaten by dotu kepala),

5. Betel Fruit (wawadi)

6. Woka (dambek, kind of palm leaves) ; betel fruit is wrapped inside woka, and then folded to the right. The wrap must have 9 ends (siow narawisna).

7. Offerings place (tinampelung). Besides woka, some other leaves must be available such as;

\section{8. dudi werot}

9. dudi pakatuan

10. dudi rahi, dudi puyu, serewung rirem, serewung kuning,

11.tontoansen, marerer, sui-sui, ketep, wudu tuy, samaran

Besides offerings, the local people also prepare for wudu and soke, bamboo filled with water. Bamboo connected with a machete at the end is called a kekeror. People also prepare for posong (a place of rice made from a kind of green woka leaf), and sosapu (grass that has been tied and stalked) to cover the holes that have been filled with paddies.

After preparing the offerings and other equipment, people participating in the ritual process are called by the tonaas to gather in the middle of the paddy field that has been previously cleaned. They stand around tonaas who squats on the hole previously made. Everybody is told to be quiet, and none of them should do anything nor speak anything. After the ceremony ends, the offerings are covered by woka leaf. It signifies the beginning of rice planting. Holes in which the paddies are planted are made by using wudu and soke or kckcror. Some farmers hold posong (a container to place paddy which is made of green woka leaf), so it would be much easier for them to plant paddies. Some carry grasses tied and connected with sosapu stalk to cover the holes in which the paddies have been planted. Kckcror and sosapu must not lie on the ground and remain stand straight. It signifies that the paddies should not die before the harvest comes. After rice planting is completed, tonaas leads the prayer. All seeds must be planted in one day. After praying, the farmers plant woku leaves used during the ritual because the symbolic meaning embedded in these leaves becomes the reality as the harvest will be fruitful. People believe that rain will fall at night to shower the paddies. This belief is always proven to be true.

\section{a. The Meaning of the Symbols}

Paddy is the a symbol of life since it becomes the main staple for the people. The verbal simbolic meaning in the rice planting represents the conventional religion system which prevails among the society. They believe the interconnection between human and the Supreme ruler 'Opo Empung'; therefore, people voice up their prayers and believe its existence not only the Creator, Preserver, Guardian, Defender, and Protector, but also as the Punisher for those who commit crimes. To show the connection with the supreme ruler, tonaas only mentions some names such as opo or dotu. like opo? Tumi?de†, opo? Mame†kas, dotu Karema, dotu Timani?, dotu Pasela mbanua. Opo? Tumi?de $\dagger$ (the bringer of paddy to the world), opo? Mame $†$ kas (the eldest in the village), dotu Karema (the companion to chew betel leaves), dotu Timani? (the opener of the field) dotu Pasela mbanua (the village guardian). Tonaas only mentions some names of Opos who have direct correlation with the cultivation of paddies. Opo' Empung as the creator is seen in the prayer Tataditan iyana ni opo? Empu†, iyana mo lime?os untana? wo u da†it (Please listen dear God who has created the earth and the sky).Opo is the Preserver, Guardian, Defender and Protector as it is represented in the sentence iyana kcdu-kcdu†an niu mokan watu? ya?ay numa ya?ay wo simbc-simbclannu lako simbcl atep simbcl iyana wo piki-piki? mu lako dukun tana? tembir tana? se sakit wo ei? simina?sa iya wia ni opo? na numa 
ya?ay. Endo kaweiten tumu?ur lako nania wo ma†e opo? (please protect and keep this rice safe and stay away from evil people and pests. Get rid all evil deeds from these rice field now and forever more).

It is believed that Opo is the punisher as it is shown in the following prayer po $†$ kolcn niu molako iyana u dee?na (just behead their neck), sa sia tuama iyana opo? mawawan $\mathrm{u} \dagger$ sompoy niu (if he is a man, let him bring your sarong), Sasia wcwene opo? ma†e madutu nikamu (if she is a woman, let her cook for you), iyana setou mada†ko-da†koy iya magcna†-gcna† lewo? iyana wia numa ya?ay ka?pa mana? niu wia numa ya?ay ka?pa ma dcdo? Numa ya?ay iyana kcnu kata opo? iyana u† santi iyana po†kolcn niu molako nsia iyana wo sia palowa-lowa?an niu moat wo endoan niu mo a†e ate sia wo u† pusu?na iyana karc †an a†e iyana scpscpen niu da?ana akar wo sia pawadi-wadin niu mokan (May everyone who will harm these paddies and do evil deeds be beheaded; their blood will be drained and their heart and liver be taken away. Thus, he will be with You forever)

The odd numbers is considered as the even number since the actor or tonaas is also counted.

The religious system contains recognition, worship and connection with the Supreme Ruler; besides, the system is also rich of teaching to do good deeds in order not to be punished by the Supreme Ruler.

The meaning in non verbal symbol embedded in the tangible materials and participants of the ritual shows the ethics. In vertical commucation, the main actor and the participants must uphold some ethics which regulate their behavior. The morning rituals signify the hopes of brightness as the sun shines in the morning. The ingredients in the offerings (tctc $† a$ ?an) represent unity. It consists of elements having their own purposes, and they are put together into the offerings. Betel leaves, areca nut and lime betel represent respects for the invited guests.It is said that dotu-dotu love chewing betel during the wars. Dudi? werot is a symbol of fertility because the leaves are lined up. Dudi? pakatu?an is a symbol of eternity. dudi? rahi, dudi? puyu, scrcwu† rircm, scrcwu† kuni†, are the symbols of power. Tontoansen, marerer, su?i-su?i, kctcp, wudu tuy , samaran are the symbols of immunity to fight against people who have evil intentions. They also symbolizes the preserver of life. The people involving in this ritual represent togetherness and mutual cooperation in accomplishing the work. This rice planting ritual is also a manifestation of the moral responsibility of the Tonsea family or community in the Wangurer village to carry out the obligations according to existing traditions

\section{b. The Functions of the Symbols}

In cultural context, symbols have very important function in human life. They interpret and reconstruct reality in creating intellectual structures in people's lives (Dharmojo, 2005:150) [4]. The functions of symbols in the field rice planting ritual are explained as follows:

1. As a social order of community life

2. As a historical fact that the belief in the correlation between the Supreme Ruler and human beings known as opo-opo is unique, exists, and grows until now.

3. As a community tradition that must be obeyed

4. As a view of life

5. As a mediation of education to comply with the norms or rules that apply in the community and the consequences of violations of these rules.

\section{CONCLUSION}

The rice field planting ritual in Tonsea ethnic is a cultural reality that has rich-meaning symbols related to feelings, emotions, and cultural and ideological values. These symbols consist of verbal and non-verbal symbols. The meaning emphasizes the preservation of nature, the balance and integration of humans and nature, respect the sacred elements, and respect leaders and supreme rulers.

Hopefully, this article can add insight to those who are studying semiotics. It is expected that the article serves as the document showing the effort to preserve the Tonsea language as one of the regional languages in North Sulawesi.

\section{ACKNOWLEDGMENT}

Grace S Luntungan, Nicolas Gosal and Prilimercy Kojongian would like to express their thankfulness to LPPM Unima for facilitating the publication of this paper.

\section{REFERENCES}

[1] P. R. Renwarin, Matuari wo Tonaas. Jakarta: Cahaya Pineleng, 2007

[2] J. M. Saruan, Agama \& Kebudayaan dalam Konteks Minahasa. Manado: Sinode GMIM, 2001.

[3] C. Geertz, Anthropological Approaches to the Study of Religion. Methuen., 1968.

[4] Dharmojo, Sistem Simbol dalam Munaba Waropen Papua. Jakarta: Pusat Bahasa Depdiknas, 2005.

[5] U. Eco, Semiotics and the philosophy of Language. Bloomington: Indiana University Press, 1983.

[6] C. A. Alwasilah, Linguistik Suatu Pengantar. Bandung: Angkasa, 1993.

[7] J. P. Spradley, Metode Etnografi. Tiara Wacana: Tiara Wacana Yogya, 1979.

[8] Koentjaraningrat, Pengantar Ilmu Antropologi. Jakarta: Rineka Cipta, 2002.

[9] M. B. Miles and A. M. Huberman, Analisis data kualitatif. Jakarta: UI press, 1992.

[10] H. Kridalaksana, Kamus Linguistik. Jakarta: PT Gramedia, 2008. 